\title{
Two-stage Decision-Making Approach to Survey the Excessive Usage of Smart Technologies
}

\author{
Daniela Borissova ${ }^{1}$, Zornitsa Dimitrova ${ }^{1}$, Magdalena Garvanova ${ }^{2}$, \\ Ivan Garvanov ${ }^{2}$, Petya Cvetkova ${ }^{2}$, Vasil Dimitrov ${ }^{1}$, Andrea Pandulis ${ }^{2}$ \\ ${ }^{1}$ Institute of Information and Communication Technologies at Bulgarian Academy of \\ Science, Sofia, Bulgaria \\ ${ }^{2}$ University of Library Studies and Information Technologies, Sofia, Bulgaria \\ Emails:dborissova@iit.bas.bg,zrn.dimitrova@gmail.com,m.garvanova@unibit.bg, \\ i.garvanov@unibit.bg,pcvetkova@abv.bg,vasil.zdimitrov@gmail.com
}

\begin{abstract}
The article discusses the decision-making problems associated with smart technologies and their usage. For the goal, a two-stage decision-making approach is proposed to survey if smart technologies are used excessively. The first part is focused on composing a survey based on a questionnaire. This investigation should cover a wide range of users of different ages. To make a suitable questionnaire to conduct such a survey a set of predefined questions is to be evaluated. The evaluation should be based on a well-defined structured technique able to motivate rational decision-making. The evaluation of the given number of questions is done by using of well-known technique that decomposes the decision problem into a hierarchy of more sub-problems (analytic hierarchy process) developed by Saaty. The questions are ranked with respect to four evaluation criteria. From the obtained ranking list of questions, the first three questions are selected to compose a questionnaire for quick conduction of survey for investigation of the impact of excessive use of smart technologies.
\end{abstract}

Keywords: Composing of surveys, decision-making, AHP, smart technologies.

\section{Introduction}

The technological development in the area of information and communication technologies resulted in the mass usage of artificial electromagnetic fields. Today, the mobile technologies are an integral part not only at the workplace, but at the home and the smart home. These technologies are used in the laptop, tablets, smartphones, 
global positioning system (GPS) devices, Wi-Fi debit/credit card terminals, etc. With rapid ICT development, many different technologies rely on GPS and Wi-Fi connectivity. Smartphones are the main sector where GPS and Wi-Fi connectivity are extensively used. The new tendency of Industry 4.0 or 5.0 along with Internet of Things is the other sector where GPS and Wi-Fi connectivity are also extremely used (Vodyaho et al., 2020, Ilchev et al., 2018). The number of smartphone users worldwide is over three billion and will further grow (O'Dea, 2020). The smart home and its integration with mobile devices also use the contemporary ICT infrastructure and connectivity. All of these portable devices utilize a variety of communications technologies, including not only Wi-Fi) and wireless cellular technologies $(3 \mathrm{G}, 4 \mathrm{G}$, and $5 \mathrm{G}$ ), but also Bluetooth connectivity, global system for mobile communications (GSM) and general packet radio service (GPRS), data services, etc. The spreading of cloud technologies contributes to increasing the use of mobile devices in business, due to flexibility to work and access over the Internet. Along with a range of benefits, these technologies also come with some disadvantages related to additional training of the staff, increased needs for IT security, and costs to purchase and on-going maintenance. On the other hand, the emerging advances in mobile phone technology as $4 \mathrm{G}$ and $5 \mathrm{G}$ open the discussions on the potential hazard for the biosphere and mankind (Markov, 2019). It is found that modulated radiofrequency (RF) electromagnetic fields could provoke specific effects from amplitude-modulated RF fields on the human central nervous system, and to establish this effect it is important to study the effect of the modulating signal (Juutilainen, et al., 2011; Blackman, 2019). There are various investigations that indicate the electromagnetic fields generated by mobile phones may cause unwanted biological changes in the human body. The authors show that long-term exposure to electromagnetic waves from GSM with $2100 \mathrm{MHz}$ frequency causes an increase in neuronal degeneration and apoptosis in the auditory system (Celiker, et al., 2017). The thermal effect of the electromagnetic waves from different GSM devices to the human body is analyzed. The results show that body temperature is increasing with increasing the duration of the conversations using a cell phone (Garvanova, et al., 2018). In addition, the emitted electromagnetic waves from different cellular mobile base stations could be measure in order to study effects on public health. The recent research compares the effect of radiated power from the base stations on people who lived near and those who live away (Salih, et al., 2019). The results show that most of the power density of the tested cells are within the acceptable range, but some of them have harmful effects in the long term for people who live near the base stations. Some possible effects of radiofrequency electromagnetic field exposure on the central nervous system are presented in (Kim et al., 2019). In addition, the influence of electromagnetic fields on the human brain is also discussed in (Garvanova, et al., 2020). All of these continuous investigations motivate the World Health Organization to classify the radiofrequency-electromagnetic field as possibly carcinogenic to humans (Baan, et al., 2011). 
The most recent research found the there are no enterprise models to reflect the effect electromagnetic "pollution" that human is exposed to (Garvanova, et al., 2020). The changing business situation requires a new type of value system, including strictly individual and socially defined functions that make their value profile more complex (Garvanova, 2019). A distinctive feature of dynamic management is the ability to generate additional knowledge and innovative solutions in the new conditions of the business environment. Therefore, good management decisions could not be made without the help of models that support decision-making at different levels, including strategic, tactical and operational. This is proved by the existence of many different models aiming to contribute to well-motivated decisions (Guliashki \& Stoyanova, 2018; Petrov, 2016). Some of them rely on business intelligence in efficiency management via single and multi-objective optimization models to cope with different situations that support business decisions via reasonable solutions (Borissova, et al., 2020a). Depending on the used decisionmaking strategy, the authors proposed a generalized approach to support the business by group decision (Borissova, et al., 2020b). These strategies refer to the determination of the most preferable alternative; determination of several good alternatives simultaneously, or ranking of all investigated alternatives with the active participation of a group of experts. The group decision-making usually involves experts with different background and competency area. To cope with such problems some new modifications able to distinguish the difference in experts' experience in the aggregated final group decision in proposed (Borissova, et al., 2019, Korsemov $\&$ Borissova. 2018). It is possible to use also the artificial neural networks to produce effective decisions, training the neural networks by different variations of genetic algorithms (Tomov, et al., 2019; Korsemov, et al., 2018). To support all of these business decisions in an easier way they should be implemented in proper software systems or suitable tools. This will contribute to building reliable IT instruments for management taking that could provide reliable cyber security (Shalamanov, 2017a; Shalamanov, 2017b).

Many decision problems could be described by the presence of a finite number of alternatives represented by their performance via multiple attributes (criteria). The problem refers to making preference decisions by evaluating and prioritizing a limited set of alternatives based on multiple conflicts attributes (Zhang, 2014). This type of problem is tackle by well-known multi-attribute decision-making techniques (MADM) or multi-criteria decision analysis (MCDA) aiming to intensify alternatives ranking regarding DM point of view to make rational selection (Georgiev et al., 2019). MCDA envelopes a set of different methods that allow performing evaluating and ranking thus facilitating the dialogue between stakeholders and decision-makers (DM). Widely used methods of MCDA are: simple multi-attribute rating technique (SMART), simple additive weighting (SAW), weighted product model (WPM), analytic hierarchy process (AHP), preference ranking organization method for 
enrichment evaluation (PROMETHEE), elimination et choice translating reality (ELECTRE), technique for order of preference by similarity to ideal solution (TOPSIS) and complex proportional assessment (COPRAS) (Zavadskas et al., 2014). Depending on the expressing of preferences the following three groups can be distinguish: utility vectors; orders of preference; and preference relations (Martinez, $\&$ Acosta, 2015). The first group considers the methods based on multi-attribute utility theory (MAUT) where all alternatives are evaluated via criteria by singlemeasure utility function that expresses the alternatives usefulness (Olson, 1996). MCDA methods that incorporate MAUT are SMART, SAW, WPM, COPRAS and AHP. The most representative methods based on outranking relation theory are families of PROMETHEE and ELECTRE (Marinova \& Guliashki, 2014; Guliashki $\&$ Kirilov, 2015; Figueira et al., 2016). The outranking methods compare the alternatives pairwise for each criterion, finding the strength of preferring one over the other. The variety of different methods to cope with MCDA give the freedom of DM to choose one of them to approach the particular problem.

Taking into account the the latest researches indicate mobile technologies influence of over human body, the current article aims to propose two-stage decisionmaking approach to survey the excessive usage of smart technologies. Considering the COVID-19 pandemic and fact that most company are working at home and rely on smart technologies such investigations could be of great importance. The main idea of the article deals with MCDA to make a ranked list of questions suitable to compose the questionnaire to conduct the survey. The rest of the article is organised as follows: Section 2 describes a two-stage decision-making approach to investigate the excessive usage of smart technologies including a proper structured technique for establishing analytic hierarchy process; Section 3 contains the obtained results related with a pair-wise comparison of evaluation criteria and given set of questions from which the selection is to be done for the goal of composing a survey; Section 4 provides the analysis and discussion of the results, while the conclusions are given in Section 5.

\section{Two-stage Decision-Making Approach to Investigate the Excessive Usage of Smart Technologies}

The problem for assessment of the psychological and physical impacts of excessive use of smart technologies could be divided into two separate parts. First of them is focused on the identification of proper means to investigate the usage of smart technologies, while the second one aims to identify the psychological and physical impacts on the human body. A graphical illustration of the problem for assessment of the psychological and physical impacts of excessive use of smart technologies is shown in Fig. 1. 


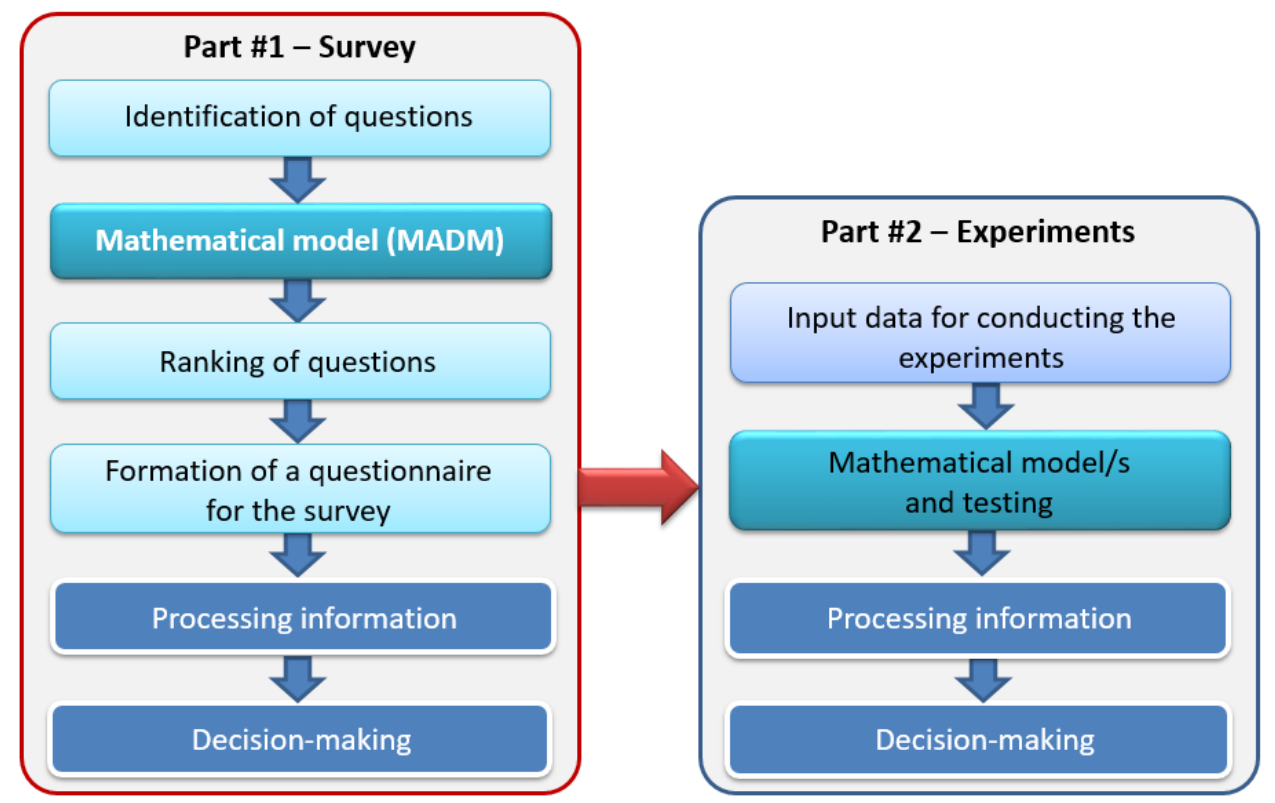

Fig. 1. Two-stage decision-making approach to survey the excessive usage of smart technologies

The problems from part \#1 are related to composing a suitable questionnaire to conduct the survey. In order for the study to be successful, it is necessary to perform some preliminary actions. In the general case, these actions are related to the identification of domain questions to be included as part of the questionnaire. At this stage, there is no restriction about the number of identified questions.

Once the questions for the investigated problem are known, all of them are to be evaluated and prioritized based on multiple attributes or established criteria. Next, it is needed to select proper MCDA techniques to evaluate the questions toward criteria. The appropriate MCDA structured techniques should be able to analyse questions and criteria to obtain the raking of questions. An authorized person should be pointed out to assess the identified questions based on the criteria and using the particular MCDA technique. For simplicity, this authorized person is considered as decision-maker. One of the possible techniques that cope with such kind of problems is the well-known analytic hierarchy process (AHP). This structured technique developed by Thomas L. Saaty belongs to the group of multi-criteria decision making methods. This approach provides a rational framework for structuring problems and quantifying its elements according to the overall goal (Saaty, 2000). It is based on a fundamental scale of numbers that indicate the importance or dominance of one element over another element with respect to the compared criterion.

The AHP approach in the context of the particular problem for composing a suitable questionnaire to conduct the survey is illustrated in Fig. 2.

At first, the DM should decompose the decision problem into a hierarchy of more sub-problems, each of which can be analysed independently. Then 
systematically evaluation of all questions (elements) by comparing each other two at a time, with respect to their impact on criteria above them in the hierarchy is to be done.

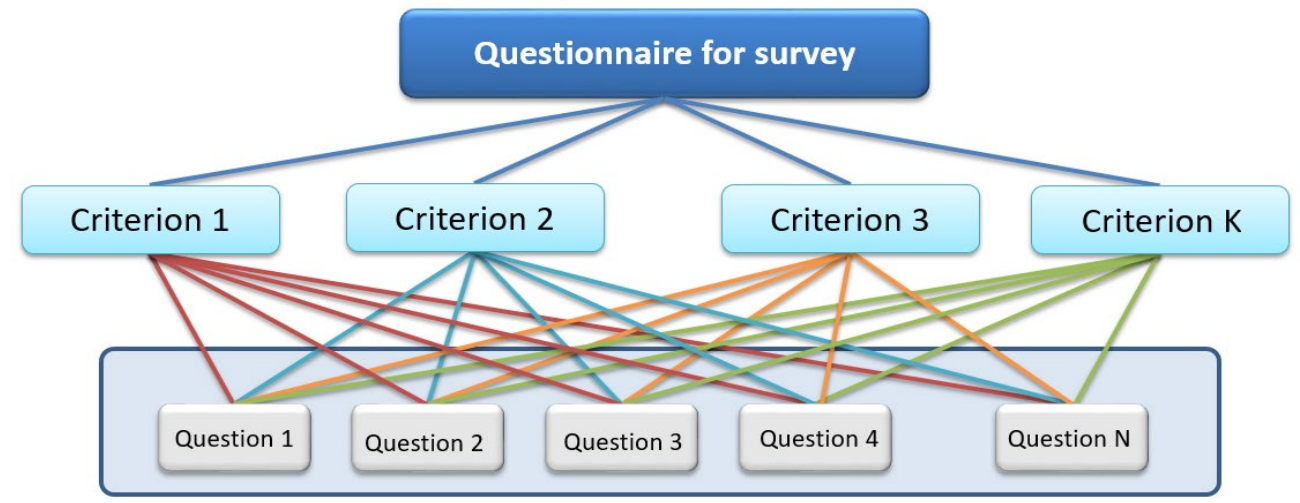

Fig. 2. AHP process for questions evaluation

During the comparisons, the decision-makers use their judgments to express the elements' relative meaning and importance. AHP converts the assigned evaluations to numerical values that could be processed and compared for the range of the problem. This is realizing by using the fundamental scale to express the intensity of importance within a range from 1 to 9 (Saaty, 1990). The meaning of numbers of this scale is shown in Table 1.

Table 1. Scale of numbers for the intensity of importance

\begin{tabular}{|c|l|}
\hline Intensity of importance & Description \\
\hline 1 & Equal importance \\
\hline 2 & Weak or slight \\
\hline 3 & Moderate importance \\
\hline 4 & Moderate plus \\
\hline 5 & Strong importance \\
\hline 6 & Strong plus \\
\hline 7 & Very strong or demonstrated importance \\
\hline 8 & Very, very strong \\
\hline 9 & Extreme importance \\
\hline
\end{tabular}

The essence of AHP is in the pairs-wise comparison instead of sorting, scoring, or the assignment of priorities. The decision-maker could rank the questions in the best way with respect to the excessive usage of smart technology and a particular decision-maker' understanding of the problem.

It should be noted that other MADM methods could be used instead AHP to evaluate and prioritize a limited set of alternatives in respect to given criteria for 
evaluation. Choosing the most appropriate MADM method is not easy because different MADM techniques may yield different results.

The information of the survey should be properly processed and analysed to answer if the smart technologies are excessively used. In the case of positive answers more or about $50 \%$, the second part of the proposed decision-making approach should be executed. It requires to involve different experts to determine the input data and to formulae proper mathematical model/s to conduct the experiments and finally - the obtained results to be interpreted.

\section{Numerical application}

The investigations in this article are focused on the first stage of the proposed approach illustrated in Fig. 1. For the goal to study how often different smart technologies are used a suitable questionnaire is to be created. To conduct such a survey, it is needed to determine a restricted number of questions that are suitable for the heterogeneous audiences. The selection should be done from predefined in advance 9 questions that are shown in Table 2.

Table 2. Questions for evaluation

\begin{tabular}{|c|c|c|}
\hline \# & \multicolumn{2}{|c|}{ Questions and possible answers } \\
\hline Q1 & $\begin{array}{l}\text { How knowledgeable are you about the } \\
\text { topic of Smart Technologies? }\end{array}$ & $\begin{array}{l}\square \text { Not at all } \\
\square \text { Not very well } \\
\square \text { Knowledgeable } \\
\square \text { Fairly } \\
\square \text { Very well }\end{array}$ \\
\hline Q2 & $\begin{array}{l}\text { Do you think you live in an urban area } \\
\text { with built an IoT infrastructure for Smart } \\
\text { City? }\end{array}$ & $\begin{array}{l}\square \text { No, I don't think } \\
\square \text { Yes, I think }\end{array}$ \\
\hline Q3 & $\begin{array}{l}\text { Is there an area with built an IoT } \\
\text { infrastructure for Smart Home near you? } \\
\text { For example, at home, at neighbours, in } \\
\text { your inhabited institutions or } \\
\text { organizations. }\end{array}$ & $\begin{array}{l}\square \text { No, there isn't } \\
\square \text { I am not informed } \\
\square \text { Yes, there is }\end{array}$ \\
\hline Q4 & $\begin{array}{l}\text { Do you think that there is a density of } \\
\text { sources of electrosmog near you, such as } \\
\text { mobile cells, routers, wireless heat and } \\
\text { water meters, or others? }\end{array}$ & $\begin{array}{l}\square \text { No, I don't think } \\
\square \text { Yes, I think }\end{array}$ \\
\hline Q5 & How often do you use a smartphone? & $\begin{array}{l}\square \text { I don't use } \\
\square \text { Not often } \\
\square \text { Fairly } \\
\square \text { Very often } \\
\square \text { All the time }\end{array}$ \\
\hline
\end{tabular}




\begin{tabular}{|c|c|c|}
\hline \# & \multicolumn{2}{|c|}{ Questions and possible answers } \\
\hline Q6 & $\begin{array}{l}\text { What are you using your smartphone } \\
\text { for? }\end{array}$ & $\begin{array}{l}\square \text { Communication } \\
\square \text { Entertainments } \\
\square \text { Work } \\
\square \text { Control of appliances in the home } \\
\square \text { Share a mobile connection by hotspot } \\
\square \text { Browsing internet } \\
\square \text { GPS Navigation } \\
\square \text { Banking and payments } \\
\square \text { Everything listed }\end{array}$ \\
\hline Q7 & $\begin{array}{l}\text { Do you find it difficult to list the } \\
\text { continents of the planet, for example, } \\
\text { without using the Internet? }\end{array}$ & $\begin{array}{l}\square \text { No } \\
\square \text { Yes }\end{array}$ \\
\hline Q8 & $\begin{array}{l}\text { Can you estimate how many degrees it is } \\
\text { outside without using Smart Device? }\end{array}$ & $\begin{array}{l}\square \text { No, I can't } \\
\square \text { Fairly } \\
\square \text { Yes, I can }\end{array}$ \\
\hline Q9 & $\begin{array}{l}\text { Can you orient yourself without GPS in } \\
\text { the city, in the mountains or while } \\
\text { driving? }\end{array}$ & $\begin{array}{l}\square \text { Not at all } \\
\square \text { Not very well } \\
\square \text { Sometimes } \\
\square \text { Fairly } \\
\square \text { Completely }\end{array}$ \\
\hline
\end{tabular}

To make the comparison between questions with respect to their suitability, four criteria are used. These evaluation criteria concern:

1) Clear and unambiguous expression $(\mathrm{C} 1)$;

2) Suitable for audience from different ages (C2);

3) Short expression without additional explanations (C3); and

4) Less options to choose from (C4).

All of these input data (questions and criteria) along with the structured technique of the analytic hierarchy process proposed by Saaty are used to make the ranking of questions with respect to the criteria importance. In the next section, the obtained results for the weights of criteria, and question comparison are described in detail.

\section{Results Analysis and Discussion}

The comparison between the determined four evaluation criteria $(\mathrm{C} 1-\mathrm{C} 4)$ is done by using the fundamental scale proposed by Saaty (Table 1). This step is important as the proper determination of the criteria weights influence in the final ranking of the questions. The evaluation criteria are compared and rated to each other against each other and the obtained results are given in Table 3. 
Table 3. Pair-wise criteria comparison matrix using Saaty's scale

\begin{tabular}{|c|c|c|c|c|c|}
\hline$\#$ & $\begin{array}{c}\text { C1 - } \\
\text { Clear \& } \\
\text { unambiguous }\end{array}$ & $\begin{array}{c}\text { C2-Suitable } \\
\text { for audience } \\
\text { from different } \\
\text { ages }\end{array}$ & $\begin{array}{c}\text { C3 - Short } \\
\text { without } \\
\text { additional } \\
\text { explanations }\end{array}$ & $\begin{array}{c}\text { C4- Less } \\
\text { options to } \\
\text { choose }\end{array}$ & $\begin{array}{c}\text { Priority } \\
\text { vector }\end{array}$ \\
\hline C1 & 1 & 9 & 1 & 4 & 0.4191 \\
\hline C2 & 0.11 & 1 & 0.14 & 5 & 0.1492 \\
\hline C3 & 1 & 7 & 1 & 0.50 & 0.2935 \\
\hline C4 & 0.25 & 0.20 & 2 & 1 & 0.1382 \\
\hline
\end{tabular}

Pair-wise criteria comparison shown in Table 3 are based on the Saaty' scale. Using these pair-wise comparisons, the following priority vector is composed [0.4191; 0.1492; 0.2935; 0.1382].

The calculated value for consistency index $(C I)$ is equal to 0.7409 , the consistency ratio $(C R)$ has value of 0.8325 , and the maximum priority vector $(\lambda)$ is equal to 6.2228. These values are obtained by using the on-line calculator (AHP Calculator - Ahpacus). The ranked list of the criteria for evaluation of the questions to composing the survey is presented in Fig. 3.

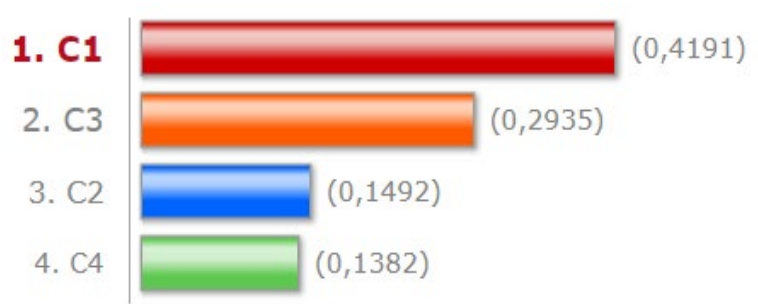

Fig. 3. Ranked list of criteria importance

It is noticeable that the DM definitely prefers criterion $\mathrm{C} 1$ that refers to the clear and unambiguous of the questions. The obtained value for criterion $\mathrm{C} 1$ is highest and is equal to 0.4191 . The second important criterion is the criterion $\mathrm{C} 3$ related to the short-expression of the questions without additional explanations. Its relative weight is equal to 0.2935 . The criterion $\mathrm{C} 2$ that refers to the suitability for the audience from different ages is ranking in third place due to its performance value, which is equal to 0.1492 . According to the particular DM' point of view, the less important criterion is $\mathrm{C} 4$ that refers to fewer options to choose for answering the question. Its performance is obviously the lowest and is equal to 0.1382 . All of this is reflected in the priority vector that contains the values of the criteria' weights.

The next step of the implementation of the analytic hierarchy process requires a pair-wise comparison between each of the formulated questions (from Table 2) toward a set of four evaluation criteria. In a such way, the DM should make 144 
pairwise comparisons for every two questions with respect to the evaluation criteria from $\mathrm{C} 1$ to $\mathrm{C} 4$. The obtained values for these comparisons are shown in Table 4.

Table 4. Questions' performance to the evaluation criteria

\begin{tabular}{|c|c|c|c|c|c|}
\hline & C1 & C2 & C3 & C4 & $\begin{array}{c}\text { Overall questions } \\
\text { performance }\end{array}$ \\
\hline Q1 & 0.1577 & 0.0387 & 0.0694 & 0.0037 & 0.2695 \\
\hline Q2 & 0.0104 & 0.0039 & 0.0253 & 0.0302 & 0.0698 \\
\hline Q3 & 0.0251 & 0.0054 & 0.0052 & 0.0159 & 0.0516 \\
\hline Q4 & 0.0060 & 0.0018 & 0.0037 & 0.0332 & 0.0447 \\
\hline Q5 & 0.0666 & 0.0147 & 0.0669 & 0.0042 & 0.1524 \\
\hline Q6 & 0.0908 & 0.0236 & 0.0708 & 0.0019 & 0.1871 \\
\hline Q7 & 0.0263 & 0.0507 & 0.0178 & 0.0278 & 0.1225 \\
\hline Q8 & 0.0282 & 0.0075 & 0.0240 & 0.0167 & 0.0764 \\
\hline Q9 & 0.0081 & 0.0030 & 0.0103 & 0.0046 & 0.0260 \\
\hline
\end{tabular}

In columns, 2 to 5 of Table 4 are shown the relative performance of the compared questions with respect to the four evaluation criteria. The latest column of Table 4 contains the values of the relative performance of each question toward all evaluation criteria.

The questions ranking as a result of conducted comparison according to each of the evaluation criteria are graphically illustrated in Fig.4.

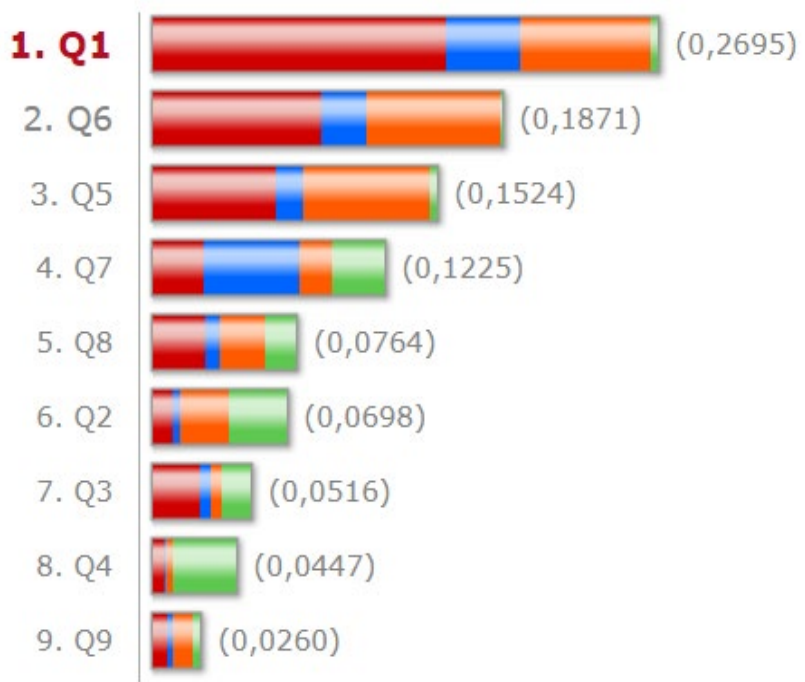

Fig. 4. Questions ranking 
The evaluation of question Q1 "How knowledgeable are you about the topic of Smart Technologies?" shows that it is the clearest, short, and suitable for different age audiences. It has the highest score of 0.1577 in accordance to the criterion $\mathrm{C} 1$, followed by values for the rest of criteria $\mathrm{C} 2, \mathrm{C} 3$, and $\mathrm{C} 4$. The second in the ranked list is the question Q6 with overall criteria performance equal to 0.1871 (Fig. 4). The third pretender that should be included as a part of the questionnaire is question Q5. Its total performance value is 0.1225 .

From Table 4 it can be seen that Question Q4 is one of the questions with the highest score of 0.0332 toward criterion $\mathrm{C} 4$. However, it is ranked in the penultimate eighth place because $\mathrm{C} 4$ is ranked as the least important criterion. To conducts the short survey, the number of questions is to be no more than 2 or 3 . That means the questionnaire should looks as shown in Table 5.

Table 5. Questionnaire for the survey

\begin{tabular}{|c|c|c|c|}
\hline \# & \multicolumn{3}{|c|}{ Questions } \\
\hline \multirow[t]{2}{*}{1} & \multicolumn{3}{|c|}{ How knowledgeable are you about the topic of Smart Technologies? } \\
\hline & $\begin{array}{l}\square \text { Not at all } \\
\square \text { Fairly }\end{array}$ & $\begin{array}{l}\square \text { Not very well } \\
\square \text { Very well }\end{array}$ & $\square$ Knowledgeable \\
\hline \multirow[t]{2}{*}{2} & \multicolumn{3}{|c|}{ How often do you use a smartphone? } \\
\hline & $\begin{array}{l}\square \text { I don't use } \\
\square \text { Very often }\end{array}$ & $\begin{array}{l}\square \text { Not often } \\
\square \text { All the time }\end{array}$ & $\square$ Fairly \\
\hline \multirow[t]{2}{*}{3} & \multicolumn{3}{|c|}{ What are you using your smartphone for? } \\
\hline & $\begin{array}{l}\square \text { Communication } \\
\square \text { Share a mobile c } \\
\square \text { GPS Navigation } \\
\square \text { Everything listed }\end{array}$ & $\begin{array}{l}\square \text { Entertainments } \\
\text { tion by hotspot } \\
\square \text { Work }\end{array}$ & $\begin{array}{l}\square \text { Control of appliances in the home } \\
\square \text { Browsing internet } \\
\square \text { Banking \& payments }\end{array}$ \\
\hline
\end{tabular}

If question Q7 could be included within the survey, this will satisfy each criterion, even the least important criterion. Therefore, instead of 3 questions, 4 questions can be included for conducting the survey on the intensive use of smart technologies.

The investigation of the excessive usage of smart technologies will give an idea of how familiar people are with the topic, for what and how often they use their smartphone, and to what extent they have become dependent on the Internet.

Once the results become available and properly processed they will indicate if the second stage of the proposed decision-making approach (see Fig. 1) is to be realized. 


\section{Conclusion}

The article aims to investigate if smart technologies are excessively used. For the goal, a short survey is to be created based on properly selected questions. Widely used multi-criteria decision-making technique, known as AHP is implemented to rank a given set of questions toward a predefined number of criteria. By following, steps of the analytic hierarchy process the ranked lists for criteria importance and questions performance with respect to all criteria are obtained. Top three questions from the ranked list are selected as the best pretenders that should be part of the questionnaire for conducting a short survey. The obtained results show the applicability of the used AHP technique for the ranking of questions to compose a questionnaire.

It should be noted, that this ranking list of questions is done by using the point of view only of one DM. To be more precise, a group of DMs could be established and different opinions to be summarized to get an aggregated decision. The group of DMs should be carefully selected and this activity is planned as a future investigation. In addition, the results from the AHP technique could be compared with other similar group decision-making methods.

\section{Acknowledgment}

This work is supported by the Bulgarian National Science Fund, Project title "Synthesis of a dynamic model for assessing the psychological and physical impacts of excessive use of smart technologies", KP-06-N 32/4/07.12.2019.

\section{References}

1. AHP Calculator - Ahpacus, http://www.123ahp.com/Default.aspx, last accessed 2020/07/17.

2. Baan, R., Grosse, Y., Lauby-Secretan, B., El Ghissassi, F., Bouvard, V., BenbrahimTallaa, L., Guha, N., Islami, F., Galichet, L., Straif, K. Carcinogenicity of radiofrequency electromagnetic fields. The Lancet Oncology 12(7), 624-626. (2011).

3. Blackman, C. Chapter 2: Cell Phone Radiation: Evidence from ELF and RF Studies. Supporting More Inclusive Risk Identification and Assessment. In: Mobile Communications and Public Health. pp. 25-46 (2019).

4. Borissova, D., D. Korsemov, I. Mustakerov. Multi-criteria Decision Making Problem for Doing Business: Comparison between Approaches of Individual and Group Decision Making. CISIM'2019, LNCS, vol. 11703, 385-396 (2019).

5. Borissova, D., D. Korsemov, N. Keremedchieva. Modelling of different strategies by new generalized algorithm for group decision-making. K. Saeed and J. Dvorsky (Eds.): CISIM 2020, LNCS vol. 12133, Springer, pp. 122-133 (2020).

6. Borissova, D., P. Cvetkova, I. Garvanov, M. Garvanova. A framework of business intelligence system for decision making in efficiency management. K. Saeed and J. Dvorsky (Eds.): CISIM 2020, LNCS vol. 12133, Springer, pp. 111-121. (2020). 
7. Celiker, M., A. Ozgur, L. Tumkaya, S. Terzi, M. Yılmaz, Y. Kalkan, E. Erdogan. Effects of exposure to $2100 \mathrm{MHz}$ GSM-like radiofrequency electromagnetic field on auditory system of rats. Brazilian Journal of Otorhinolaryngoly 83(6), 691-696 (2017).

8. Figueira, J.R., Mousseau, V., Roy, B.: ELECTRE Methods. In: Greco S., Ehrgott M., Figueira J. (eds) Multiple Criteria Decision Analysis. International Series in Operations Research \& Management Science, vol. 233 (2016). https://doi.org/10.1007/978-1-49393094-4 5.

9. Garvanova, M. The digital entrepreneurship as a new generation software of the mind. In: Ivanova, S.V., Elkina, I.M. (eds.) icCSBs'2019, Future Academy, vol. LXXIV, pp. 294-300 (2019).

10. Garvanova, M., Garvanov, I., Borissova, D.: Influence of electromagnetic fields on human brain. In: 21st International Symposium on Electrical Apparatus and Technologies - SIELA 2020, pp. 1-4. Bourgas, Bulgaria (2020).

11. Garvanova, M., Garvanov, I., Kashukeev, I.: Business Processes and the Safety of Stakeholders: Considering the Electromagnetic Pollution. In: Shishkov B. (eds) Business Modeling and Software Design. BMSD 2020. Lecture Notes in Business Information Processing, vol. 391, pp. 386-393.

12. Garvanova, M., Shishkov, B., Vladimirov, S.: Mobile devices - effect on human health. In: B. Shishkov (Ed.), Proc. of Seventh International Conference on Telecommunications and Remote Sensing - ICTRS'18, October 8-9, 2018, Barcelona, Spain, 101-104. https://doi.org/10.1145/3278161.3278176.

13. Georgiev, P., Garbatov, Y., Kirilov, L., Denev, Y.: Multi attribute design decision solution of MPV accounting for shipyard building constraints. In: Proc. IMAM 2019, Sustainable Development and Innovations in Marine Technologies, pp. 354-361, Taylor \& Francis, (2019), https://doi.org/10.1201/9780367810085.

14. Guliashki V., Stoyanova K. Portfolio Risk Optimization Based on MVO Model. In K. Dimitrov, N. S. Doncov, C. Mitrovski (eds.), ICEST’2018, 67-70 (2018).

15. Guliashki, V., Kirilov, L.: A Promethee-based approach to multi-criteria flexible job shop scheduling problem. In: Dimitrov K. (ed.) International Scientific Conference on Information, Communication and Energy Systems and Technologies ICEST'2015, pp. 113-116. (2015).

16. Ilchev, S., Andreev, R., Ilcheva, Z.: Heterogeneous IoT platform for device management and environmental sensor data gathering. Serdica Journal of Computing 12(1-2), 23-45 (2018).

17. Juutilainen, J., A. Hoyto, T. Kumlin, J. Naarala. Review of possible modulationdependent biological effects of radiofrequency fields. Bioelectromagnetics 32(7), 511534. (2011).

18. Kim, J. H., Lee, J.-K., Kim, H.-G., Kim, K.-B., Kim, H. R.: Possible effects of radiofrequency electromagnetic field exposure on central nerve system. Biomolecules \& Therapeutics 27(3), 265-275 (2019).

19. Korsemov, Ch., S. Koynov, H. Toshev. An Approach to Training Artificial Neural Networks with Genetic Algorithms. Problems of Engineering Cybernetics and Robotics 70, 3-11 (2018).

20. Korsemov, D., D. Borissova. Modifications of simple additive weighting and weighted product models for group decision making. Advanced Modeling and Optimization 20(1), 101-112 (2018).

21. Marinova, G., Guliashki, V.: A PROMETHEE - Based Approach for Multiple Objective Voltage Regulator Optimization. In: Mladenov V.M., Ivanov P.C. (eds) Nonlinear 
Dynamics of Electronic Systems. NDES'2014. Communications in Computer and Information Science, vol. 438, pp. 100-113. (2014) https://doi.org/10.1007/978-3-31908672-9_14.

22. Markov, M.: Chapter 1: Mobile Communications and Public Health. Taylor \& Francis Group, pp. 1-23. (2019).

23. Martinez, D.L.L.R., Acosta, J. C.: Review of modeling preferences for decision models. European Scientific Journal 11(36) (2015). http://eujournal.org/index.php/esj/article/view/6748).

24. O’Dea, S.: Smartphone users worldwide 2016-2021. https://www.statista.com/statistics/330695/number-of-smartphone-users-worldwide/, last accessed 2020/07/02.

25. Olson, D.L.: Multiattribute Utility Theory. In: Decision Aids for Selection Problems. pp. 19-33. (1996). https://doi.org/10.1007/978-1-4612-3982-6_3

26. Petrov, I.: Improving the methodology of market structures analysis with innovative concepts for phase-structure states and set concentration index. Journal Economic Alternative 1, 5-15 (2016).

27. Saaty, T. L. Fundamentals of Decision Making and Priority Theory with the Analytic Hierarchy Process. RWS Publications, 477 pages (2000).

28. Saaty, T. L. How to make a decision: The Analytic Hierarchy Process. European Journal of Operational Research 48(1), 9-26 (1990).

29. Salih, Al-H. A., Saeed. A.T., Saber, Z. R.: A study on the effects of cellular mobile networks on people in Tikrit city based on power density measurements and calculations. Engineering, Technology \& Applied Science Research 9(3), 4265-4270 (2019).

30. Shalamanov, V.: Institution Building for IT Governance and Management. Information \& Security: An International Journal 38, 13-34 (2017).

31. Shalamanov, V.: Towards Effective and Efficient IT Organizations with Enhanced Cyber. Information \& Security: An International Journal 38, 5-10 (2017).

32. Tomov, P., Zankinski, I., Balabanov, T.: Training of artificial neural networks for Financial time series forecasting in android service and widgets. Problems of Engineering Cybernetics and Robotics 71, 50-56 (2019).

33. Vodyaho, A., Yoshinov, R., Zhukova, N., Thaw, A.M., Ahmed Saddam A.: Fog oriented model for data collection in the networks of mobile devices. In: 2020 IEEE 10th International Conference on Intelligent Systems (IS), pp. 421-425 (2020), doi: 10.1109/IS48319.2020.9200138.

34. Zavadskas, E.K., Turskis, Z., Kildiene, S.: State of art surveys of overviews on MCDM/MADM methods. Technological and Economic Development of Economy 20, 165-179 (2014).

35. Zhang, L.: Multi-attribute Decision Making. In: Michalos A.C. (eds) Encyclopedia of Quality of Life and Well-Being Research. Springer, Dordrecht. (2014). https://doi.org/10.1007/978-94-007-0753-5_1863. 